countries who have already consented to act in that capacity include Prof. A. Fowler, Prof. H. Dingle and Dr. S. Judd Lewis of London; and Prof. O. S. Duffendack, Prof. J. A. Harrison and Dr. Lester W. Strock of the United States. The first number of the journal will probably be published in May. The English editor will be pleased to receive papers in English on the subject, which should be addressed to: The Editor, Spectrochimica Acta, 98 St. Pancras Way, London, N.W.1.

\section{University Co-operation}

THE recently published report of the Executive Council of the Universities Bureau of the British Empire announces preliminary steps towards bringing about an informal conference between some of the heads of universities in the United States of America and those of universities in the British Empire. In the course of a trans-Atlantic tour undertaken last spring, primarily with the object of cultivating helpful relations with the Canadian universities, the secretary of the Bureau got into touch with the presidents of Harvard and Yale, the president of the Carnegie Corporation of New York and the director of the Institute of International Education, and discussed with them the possibility of a visit to England of some of the heads of universities in the United States in 1941, when the sixth quinquennial congress of the Universities of the British Empire will be held in Manchester.

\section{Announcements}

Twe Secretary of State for Air, Sir Kingsley Wood, on the recommendation of the Director of Medical Services, Royal Air Force, has appointed the following standing committee to investigate and advise him on the medical aspects of all matters concerning personnel which might affect safety and efficiency in flying: Sir Edward Mellanby (chairman), Prof. F. C. Bartlett, Mr. E. A. Carmichael, Mr. C. S. Hallpike, Dr. B. H. C. Matthews, Sir John Parsons and Prof. L. J. Witts. The representatives of the Air Ministry on the Committee will be Air Vice-Marshal A. V. J. Richardson, director of Medical Services, and Air Commodore H. E. Whittingham.

THE following have been elected officers of the Physical Society for the year ending March 1940: President, Prof. Allan Ferguson; Vice-Presidents, Prof. G. I. Finch, Dr. Ezer Griffiths, Dr. L. Hartshorn, Mr. R. W. Paul; Hon. Secretaries, Mr. J. H. Awbery, Dr. W. Jevons; Hon. Foreign Secretary, Prof. O. W. Richardson; Hon. Treasurer, Dr. C. C. Paterson; Hon. Librarian, Dr. J. H. Brinkworth.

THE following have been elected officers of the Geological Society of London for the ensuing year : President, Prof. H. H. Swinnerton; Vice-Presidents, Dr. E. B. Bailey, Prof. W. G. Fearnsides, Prof. O. T. Jones, and Prof. C. E. Tilley; Secretaries, Dr. I. Hawkes and Prof. W. B. R. King ; Foreign Secretary, Sir Arthur Smith Woodward; Treasurer, Mr. F. N. Ashcroft.
THE following have been elected officers of the Quekett Microscopical Club for the ensuing year: President, W. E. Watson Baker; Vice-Presidents, H. G. Brown, C. H. Caffyn, D. J. Scourfield, P. K. Sartory ; Hon. Treasurer, Dr. C. L. Odam ; Secretary, Miss C. Arnold ; Reporter, A. Morley Jones ; Curator, C. J. Sidwell ; Assistant Curator, W. F. Reeve ; Librarian, H. C. G. Best ; Editor, W. P. Sollis.

THE following appointments and promotions have recently been made in the Colonial Service: A. J. Hans, veterinary officer, Kenya; Dr. S. E. Piercy, veterinary research officer, Kenya; Dr. R. B. McConnell, assistant field geologist, Tanganyika Territory; P. A. Loizides, agricultural chemist, Cyprus; R. J. Lathbury, senior plant breeder, Agricultural Department, Kenya; R. G. H. Wilshaw, senior chemist (soils), Malayan Agricultural Service; H. G. Pudney, senior inspector of produce, Agricultural Department, Nigeria.

The Leslie Dana Gold Medal awarded annually by the Association for Research in Ophthalmology and the St. Louis Society for the Blind was recently presented to Prof. Ellice M. Alger for his contributions to ophthalmology during the last thirty years and his work as a teacher. For many years he had been professor of clinical ophthalmology at the New York Postgraduate Medical School.

A CONFERENCE and working demonstration on "Pure Fruit Juices and Syrup" will be held at the Long Ashton Research Station of the Department of Agriculture and Horticulture, University of Bristol, on March 23. Further information can be obtained from the Director, Research Station, Long Ashton, near Bristol.

THE French Association for the Advancement of Science will meet this year at Liège on July 17-22, under the presidency of Prof. C. Fabry, director of the Optical Institute, Paris. The local committee for the meeting is under the chairmanship of Prof. Dehalu, of the University of Liège.

A Flemish Academy of Medicine, consisting of six sections, has recently been founded at Brussels.

The fifth International Congress for First Aid will be held at Zurich and St. Moritz on July 23-28.

THE eighteenth Congress of the German Association for Microbiology will be held in Vienna on March 2730. Further information can be obtained from the Secretary, Prof. Wohlfeil, Führerstrasse 2, Berlin, N.15.

REPRESentatives of thirty-five countries will attend the tenth International Congress of Military Medicine and Pharmacy, which is to be held at Washington on May 7-15. Further information can be obtained from the Secretary-General of the Congress, Army Medical Library, Washington, D.C. 